\section{Can Inorganic Bovine Bone Grafts Present Distinct Properties?}

Fernanda de Paula do Desterro ${ }^{1}$, Márcia Soares Sader ${ }^{2}$, Glória Dulce de Almeida Soares ${ }^{2}$, Guaracilei Maciel Vidigal Jr,4

\author{
'Department of Oral Implantology, \\ Unigranrio University, Duque \\ de Caxias, RJ, Brazil \\ ${ }^{2}$ Department of Metallurgical and \\ Materials Engineering, UFRJ - Federal \\ University of Rio de Janeiro, RJ, Brazil \\ ${ }^{3}$ Postdoctoral in Periodontics, School \\ of Dentistry, UERJ - State University \\ of Rio de Janeiro, RJ, Brazil \\ ${ }^{4}$ Department of Oral Surgery and \\ Periodontics, USP - University of São \\ Paulo, Ribeirão Preto, SP, Brazil
}

Correspondence: Dra. Fernanda de Paula do Desterro, Rua Conde de Bonfim, 232 sala 701 Tijuca, 20520054 Rio de Janeiro, RJ, Brasil Tel: 5521-99609-7215, 55-21-2284-0539. e-mail: fernandadesterro@ig.com.br

Key Words: biomaterials, hydroxyapatite, physicochemical characterization, bovine bone mineral.

\section{Introduction}

Correct positioning is a key factor in esthetic and functional dental implant treatment, and it is essentially determined by the adequate amount of soft and hard tissues (1). Various treatment modalities, including bone grafting biomaterials, have been employed to achieve bone augmentation to allow proper implant installation. For this objective natural bone grafting biomaterials can be obtained from different origins: autogenous, allogenous, and xenogenous. Autogenous bone grafts are commonly associated with a second surgical site, increasing the treatment morbidity, and a limited amount of bone tissue (2). The allogenous bone grafts are associated with disease transmission risk (3). Xenogenous materials have been extensively researched and present a history of results. They have been successfully used to maintain the dimensions of the post-extraction alveolar ridge; in the treatment of alveolar process defects and maxillary sinus lifting $(4,5)$.

Natural bone presents two major constituents: organic and inorganic. The organic bone matrix is composed of collagen, proteoglycans and glycoproteins (6). The collagen is frequently used to manufacture membrane barriers for guided bone regeneration (7). The major constituent of the inorganic part of bone is hydroxyapatite $(\mathrm{HA})$ and it is used for inorganic bone grafts (5). Inorganic bone grafts should function like a bone remodeling base to be replaced by the host bone. This remodeling process is associated with the physicochemical properties of the HA. Although the inorganic phase of bone is commonly referred to as
$H A$, it is actually a carbonated hydroxyapatite, which has crystallinity and chemical composition similar to human bone (8). The crystals are deposited on the collagen, which was first deposited, forming a composite biomaterial (6). The collagen forms long fibers and their association with the HA crystals results in bone strength (6). During the manufacture of inorganic bone grafts, thermal treatments are employed to remove the organic part of the bone (9). Temperatures above $900{ }^{\circ} \mathrm{C}(10)$ used in this process may change the atomic structure of the HA crystal (11), which may strongly affect the graft behavior $(6,9)$.

Several bovine bone-derived inorganic biomaterials have been commercialized (12). However, the fact that different biomaterials have the same origin may not guarantee the same biological and clinical results (13). The differences in the manufacturing process of biomaterials may cause changes in the physicochemical properties of the bovine bone. Thus, the purpose of this study was to evaluate the physicochemical characteristics of three inorganic bovine biomaterials and determine the relationship with their dissolution rates.

\section{Material and Methods}

The analyzed inorganic bovine bone biomaterials were Bio-Oss ${ }^{\circledast}$ (GeistlichPharma AG, Wolhusen, Switzerland), GenoxInorgânico ${ }^{\oplus}$ (Baumer, São Paulo, SP, Brazil), and Bonefill $^{\oplus}$ (Bionnovation, Bauru, SP, Brazil). The techniques employed for physicochemical characterization of the biomaterials included field emission gun scanning 
electron microscopy (FEG-SEM), Fourier transform infrared spectroscopy (FTIR), X-ray diffraction (XRD), determination of calcium/phosphorus ratio, and dissolution test.

\section{FEG-SEM}

Morphological characterization of the three biomaterials was performed with a field emission gun scanning electron microscope with increasing magnification (Quanta 400F; FEI Company, Oregon, USA). The samples, in their commercial form, were mounted on stubs and sputter-coated with gold at $10 \mathrm{~mA}$ for $120 \mathrm{~s}$ (Emitech K550 Sputter Coater, Emitech Ltd., Ashford, Kent, UK) with.

\section{FTIR}

The characteristic absorption bands for calcium phosphate were identified by FTIR. To prepare the samples, 1 $\mathrm{mg}$ of each biomaterial was mixed with $150 \mathrm{mg}$ of potassium bromide $(\mathrm{KBr})$ followed by pressing at 10,000 psi with a hydraulic press (Carver laboratory press, mode $\mathrm{C}_{\text {; }}$ Fred $\mathrm{S}$. Carver Inc., Wabash, IN, USA). The used spectrometer was FIIR Spectrum 100 (PerkinElmer Brazil Ltd., São Paulo, SP, Brazil). The spectra were collected at room temperature and recorded from 400 to $4000 \mathrm{~cm}^{-1}$.

\section{$X R D$}

The crystalline phases of the crushed commercial samples were identified by XRD. The Shimadzu XRD-6000 $\mathrm{X}$-ray diffractometer (Shimadzu Corporation, Chiyoda-ku, Tokyo, Japan) was used with $\mathrm{Cu} \mathrm{K} \alpha$ radiation, operating at $30 \mathrm{kV}$ and $30 \mathrm{~mA}$. Scanning in $2 \theta$ was $3^{\circ}-80^{\circ}$, in $0.02^{\circ}$ steps $(2 \theta)$. The obtained diffractograms were analyzed using Match Phase Analysis Report (Crystal Impact, Bonn, Germany). The crystallite size was calculated using the Scherrer equation (14): $L=K \lambda / \beta \cos \theta$.

\section{BET Surface Area Analysis}

The specific surface area of each biomaterial was calculated based on the amount of nitrogen required to physically adsorb to the surface sample completely dry, at different pressures (Fig. 1). The physical adsorption is caused by van der Waals forces between molecules of the gas and atoms or ions of the sample. The physisorption analyzer ASAP 2020 model (Micromeritics Instrument Corporation, Norcross/Atlanta, GA, USA) was used. The samples were subjected to pre-treatment at $200^{\circ} \mathrm{C}$, specific for hydroxyapatites.

\section{Calcium/Phosphorus Molar Ratio}

For the analysis of initial calcium, $50 \mathrm{mg}$ of each biomaterial powder was weighed and dissolved in $1 \mathrm{~mL}$ of $5 \%$ nitric acid, in a $50-\mathrm{mL}$ volumetric flask using double distilled water. A $250-\mu \mathrm{L}$ aliquot of this solution was transferred into another $50-\mathrm{mL}$ volumetric flask to make a 200x dilution in double distilled water. The $0.2 \%$ potassium chloride (VETEC Fine Chemicals LTD, Duque de Caxias, RJ, Brazil) was used to suppress ionization in atomic absorption. The released calcium was measured by atomic absorption (Shimadzu, model AA 6800; SINC Brazil, São Paulo, SP, Brazil).

The same steps in the analysis of calcium were followed for the analysis of initial phosphorus, except the use of potassium chloride. The $0.1 \%$ nitric acid was used to ensure that the phosphate ion was always detectable as $\mathrm{PO}_{4}{ }^{3-}$. Measurements were conducted using an ultravioletvisible spectrophotometer (UV-VIS) (Lambda 25 Model; PerkinElmer Brazil LTD, São Paulo, SP, Brazil). One $\mathrm{mL}$ of sample, $1 \mathrm{~mL}$ of $4 \%$ ferrous sulfate, and $1 \mathrm{~mL}$ of $2 \%$ ammonium molybdate were used. The concentration of phosphorus was measured using a 700-nm wavelength.

\section{Dissolution Assay}

The granular biomaterials, in their commercial form, were passed through a 420- $\mu$ m screen (Granutest; Telastem Peneiras para Análises Ltda, São Paulo, SP, Brazil) and were retained on a 350- $\mu \mathrm{m}$ screen using the dry screen method (15). The resulting particles were separated into Falcon tubes and evaluated at different time points, namely 7, 24, $48,72 \mathrm{~h}$ and $168 \mathrm{~h}$. Each test was performed in triplicate, requiring a total of 45 Falcon tubes. The dissolution test was performed using $0.1 \mathrm{M}$ potassium acetate buffer solution (VETEC) under air atmosphere, $\mathrm{pH} 5$, and at $37^{\circ} \mathrm{C}$. The reagent was weighed $(9.814 \mathrm{~g})$ and adjusted to $\mathrm{pH} 5$ using a $0.5 \mathrm{M}$ acetic acid solution (VETEC). The particles were suspended at a ratio of approximately $0.10 \mathrm{~g}$ of dry powder in $2 \mathrm{~mL}$ of buffer solution. Quantification of the material was conducted according to ISO/FDIS 10993-14:2001 (16). At the end of each time point, the supernatant was pipetted and diluted 200x in double distilled water, as previously described. The amount of released calcium was measured by atomic absorption (Shimadzu Model AA 6800l).

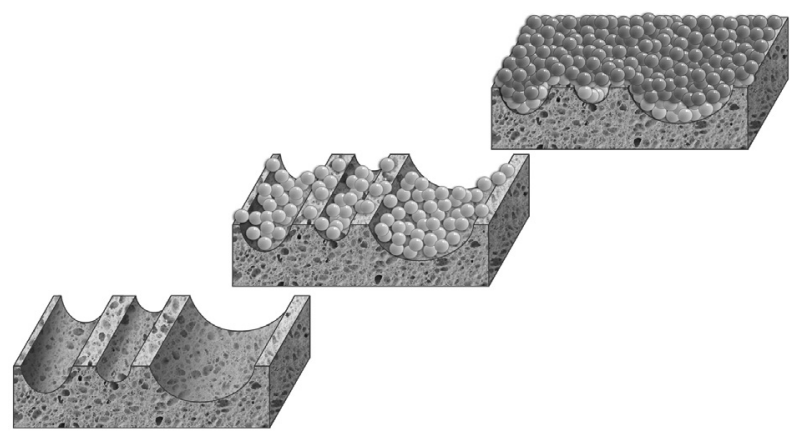

Figure 1. Schematic representation of the physical adsorption of nitrogen to the surface sample. Increasing gas pressure will cause the beginning of multi-layer coverage. 


\section{Statistical Analysis}

The results of calcium released from samples during dissolution tests were compared using the statistical software package Origin ${ }^{\circledR} 8.0$ (OriginLab, Northampton, MA, USA). Histogram normality test on each group of data was performed to determine whether it follows a normal distribution. Then, one-way ANOVA followed by the Tukey's test was used to determine statistically significant differences. The significance level was set at 0.05 .

\section{Results}

\section{FEG-SEM}

FEG-SEM analysisshowed micro and nano-morphological differences among the various analyzed bone grafts. At $1,000 \times$ magnification, micropores were observed within a diameter range of 40-70 $\mu \mathrm{m}$ associated with spaces of the Haversian blood vessel system (Figs. 2A and 2B). Bonefill ${ }^{\odot}$ possessed a fibrous structure (Fig. 2C). Using 10,000x magnification, the morphological differences among Bio-Oss ${ }^{\oplus}$, Genox ${ }^{\oplus}$, and Bonefill ${ }^{\oplus}$ were more accentuated. Bio-Oss ${ }^{\oplus}$ showed a mineral scaffold organization similar to the collagen fibers (Fig. 3A). Genox ${ }^{\oplus}$ did not show the same organized structure and exhibited greater HA particle sizes. Microscopic pores, presenting polyhydric shapes, were observed among the particles (Fig. 3B). Bonefill ${ }^{\circledast}$ consisted of some micropores on its outer surface, with the HA particles forming a single body, thus hindering visualization of individual particles at this specific magnification stage (Fig. 3C). Figs. 4A and 5A show nanopores on the surface of Bio-Oss ${ }^{\oplus}$. Genox ${ }^{\circledast}$ had micropores (Fig. 3B) but no nanopores were visualized (Figs. $4 \mathrm{~B}$ and $5 \mathrm{~B}$ ). Bonefill ${ }^{\oplus}$ also presented nanopores, similar to Bio-Oss ${ }^{\oplus}$, but they were observed only at 50,000 $\times$ and 100,000 $\times$ magnifications (Figs. 4C and 5C). Surface texture of the powder particles varied from rough (Figs. 5A and 5C) to smooth (Fig. 5B).

\section{FTIR}

Variations in the vibration modes of the functional groups were observed using the infrared spectra (Fig. 6). The higher intensities of the absorption bands for $\mathrm{CO}_{3}{ }^{2-}$ $\left(v_{3}\right)$ at 1,463 and $1,412 \mathrm{~cm}^{-1}$ and for $\mathrm{CO}_{3}{ }^{2-}\left(v_{2}\right)$ at $872 \mathrm{~cm}^{-1}$ reflect a higher incorporation of carbonate in the apatite. The resolution of the absorption band of $\mathrm{PO}_{4}{ }^{3-}\left(v_{3}\right)$ at 1,032 $\mathrm{cm}^{-1}$ diminished with increasing $\mathrm{CO}_{3}{ }^{2-}$, as seen in the FIIR spectrum of Bio-Oss ${ }^{\oplus}$. The 1,463, 1,412 and $872 \mathrm{~cm}^{-1}$ bands correspond to $\mathrm{CO}_{3}{ }^{2-}$ replacing $\mathrm{PO}_{4}{ }^{-3}$, thus characterizing the biomaterial as a calcium-deficient and carbonate-rich HA. The 1,641 band corresponds to $\mathrm{H}_{2} \mathrm{O}$, it has higher resolution in the FIIR spectrum of Bio-Oss ${ }^{\oplus}$. The 964 band
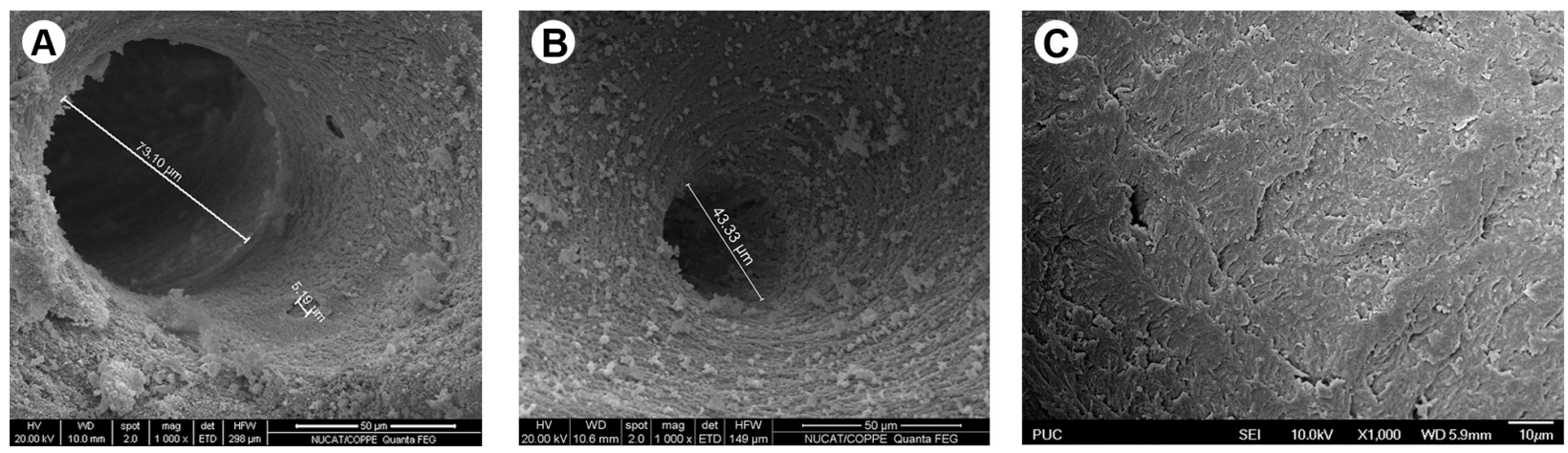

Figure 2. A: Bio-Oss ${ }^{\infty}$. Measurement of the Haversian system: $73.10 \mu \mathrm{m}$. Measurement of osteoplast: $5.19 \mu \mathrm{m}$. B:- Genox ${ }^{\infty}$. Measurement of the Haversian system: $43.33 \mu \mathrm{m}$. C: Bonefill ${ }^{\infty}$. Notice the fibrous structure of the bone. Original magnification 1,000x.
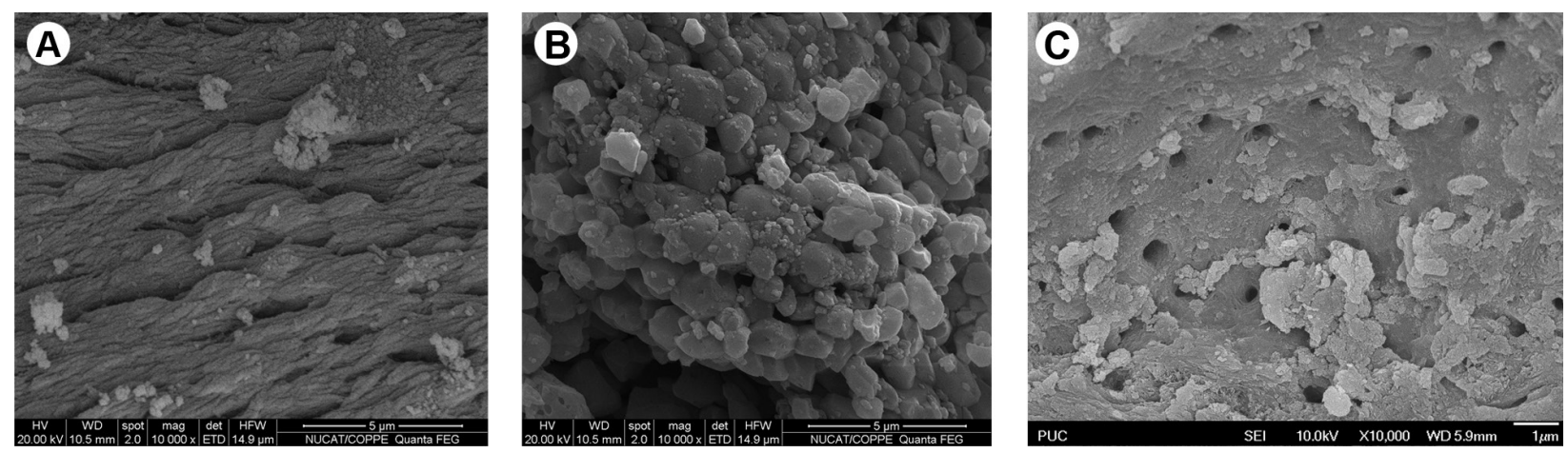

Figure 3. A: Bio-Oss ${ }^{\infty}$. Mineral scaffold organization similar to the collagen fibers. B: Genox ${ }^{\infty}$. Notice the greater HA particle size. C: Bonefill ${ }^{\circledR}$. Micropores on its outer surface. Original magnification 10,000x. 
corresponds to $\mathrm{PO}_{4}{ }^{3-}\left(v_{1}\right)$, the 568 band corresponds to $\mathrm{PO}_{4}{ }^{3-}\left(v_{4}\right)$, and the 472 band corresponds to $\mathrm{PO}_{4}{ }^{3-}\left(v_{2}\right)$, all present in Bio-Oss ${ }^{\bullet}$ and GenoxInorgânico ${ }^{\oplus}$. The crystalline hydroxyapatite generates two characteristic $\mathrm{OH}$ bands of approximately 3,562 and $630 \mathrm{~cm}^{-1}$. These bands are present in the FIIR spectrum of GenoxInorgânico ${ }^{\oplus}$. There is a higher resolution of the absorption band of $\mathrm{PO}_{4}{ }^{3-}\left(v_{3}\right)$ at $1,032 \mathrm{~cm}^{-}$ 1 and a decrease in the absorption band for carbonate, indicating a lower rate of replacement of $\mathrm{PO}_{4}{ }^{-3}$ by $\mathrm{CO}_{3}{ }^{2-}$ in GenoxInorgânico ${ }^{\circledR}$. The 1,382 band corresponds to $\mathrm{NO}_{3}{ }^{-}$, and it is present in the FTIR spectrum of Bonefill ${ }^{\oplus}$. However, the absorption bands of $\mathrm{PO}_{4}{ }^{3-}$ are poorly defined in Bonefill ${ }^{\oplus}$.

\section{$X R D$}

$\mathrm{X}$-ray diffractograms of the analyzed biomaterials were compared with diffractometric patterns of individual phases available at the International Centre for Diffraction Data (ICDD) for the various calcium phosphates. The increase in the $\mathrm{CO}_{3}{ }^{2-}$ content caused a reduction in crystallinity of apatites, as indicated by the peak broadening of XRD (Fig. 7). Bio-Oss ${ }^{\circledast}$ showed a HA crystallite size of $15 \mathrm{~nm}$, lower crystallinity, and X-ray diffractograms indicative of carbonated hydroxyapatite [00-004-0697] and Whitlockite [00-006-0426]. Genox ${ }^{\oplus}$ consisted of HA with a crystallite size of $39 \mathrm{~nm}$ and higher crystallinity identified by higher and narrower diffraction peaks in [002] and [300] planes. The XRD diffractogram of Genox ${ }^{\oplus}$ showed main peaks that were related to hydroxyapatite (00-024-0033). For Bonefill ${ }^{\oplus}$, it was not possible to calculate its crystallite size because the biomaterial was highly amorphous.

\section{BET Surface Area Analysis}

Bio-Oss ${ }^{\oplus}$ showed a greater surface area of approximately $86 \mathrm{~m}^{2} / \mathrm{g}$, whereas GenoxInorgânico ${ }^{\circledast}$ had a specific surface area of $<10 \mathrm{~m}^{2} / \mathrm{g}$. It was not possible to determine the specific surface area of Bonefill ${ }^{\oplus}$.

\section{Calcium/Phosphorus Molar Ratio}

The average mass fractions of calcium in Bio-Oss ${ }^{\oplus}$, GenoxInorgânico ${ }^{\circledast}$ and Bonefill ${ }^{\oplus}$ were $33.52 \pm 1.20,35.49$ \pm 0.77 , and $23.63 \% \pm 0.44$, respectively. The average mass fractions of phosphorus in Bio-Oss ${ }^{\circledast}$, GenoxInorgânico ${ }^{\oplus}$ and Bonefill $^{\varpi}$ were $15.74 \pm 1.41,17.36 \pm 0.53$, and $17.64 \% \pm$ 2.46 , respectively. Consequently, the molar $\mathrm{Ca} / \mathrm{P}$ ratios of Bio-Oss ${ }^{\oplus}$, GenoxInorgânico ${ }^{\circledast}$, and Bonefill ${ }^{\circledast}$ were $1.65,1.58$, and 1.03 , respectively.

\section{Dissolution Assay}

The release of calcium in an acid solution is shown in Figure 8 . In the analysis of materials, Bio-Oss ${ }^{\oplus}$ and Bonefill ${ }^{\odot}$
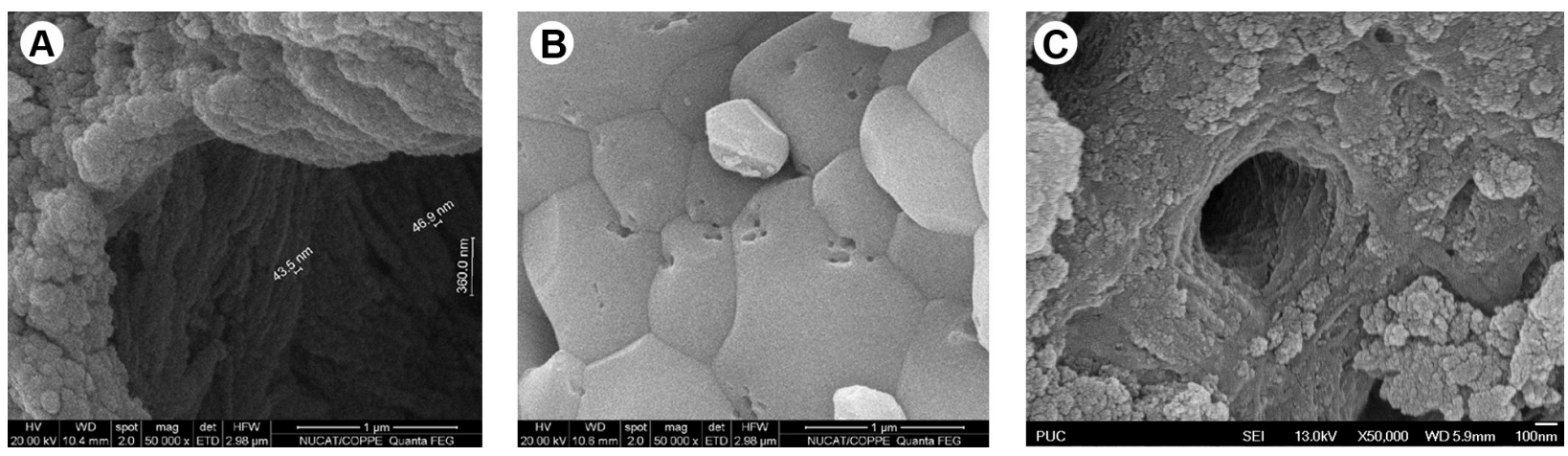

Figure 4. A: Bio-Oss ${ }^{\circledast}$. Measurement of nanotubules: $43.5 \mathrm{~nm}$ and $46.9 \mathrm{~nm}$. B: Genox ${ }^{\circledast}$. FEG-SEM image suggestive of a sintered HA in high temperature. C:- Bonefill ${ }^{\Phi}$. Original magnification 50,000x.
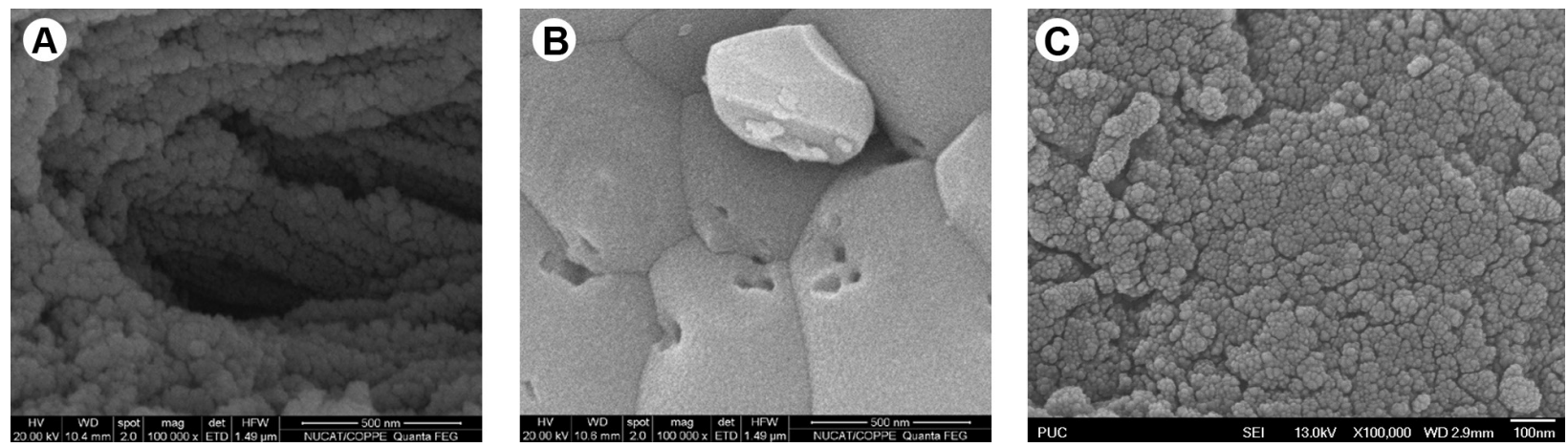

Figure 5. A: Bio-Oss ${ }^{\varpi}$. Presence of nanopores. B: Genox ${ }^{\circledR}$. Smooth surface texture without nanopores. C: Bonefill ${ }^{\oplus}$. Presence of nanopores. Original magnification 100,000x. 
when compared with GenoxInorgânico ${ }^{\circledast}$. According to the results of the dissolution assay, the behaviors of Bio-Oss ${ }^{\circledast}$ and Bonefill ${ }^{\oplus}$ were not statistically different in the amount of released calcium, and the behavior of GenoxInorgânico ${ }^{\odot}$ was statistically different from Bio-Oss ${ }^{\oplus}$ at 24,72 and $168 \mathrm{~h}$.

No statistically significant differences were observed when the dissolution time for each material was changed.

\section{Discussion}

The FEG-SEM images (Fig. 3) showed that Bio-Oss ${ }^{\oplus}$ was

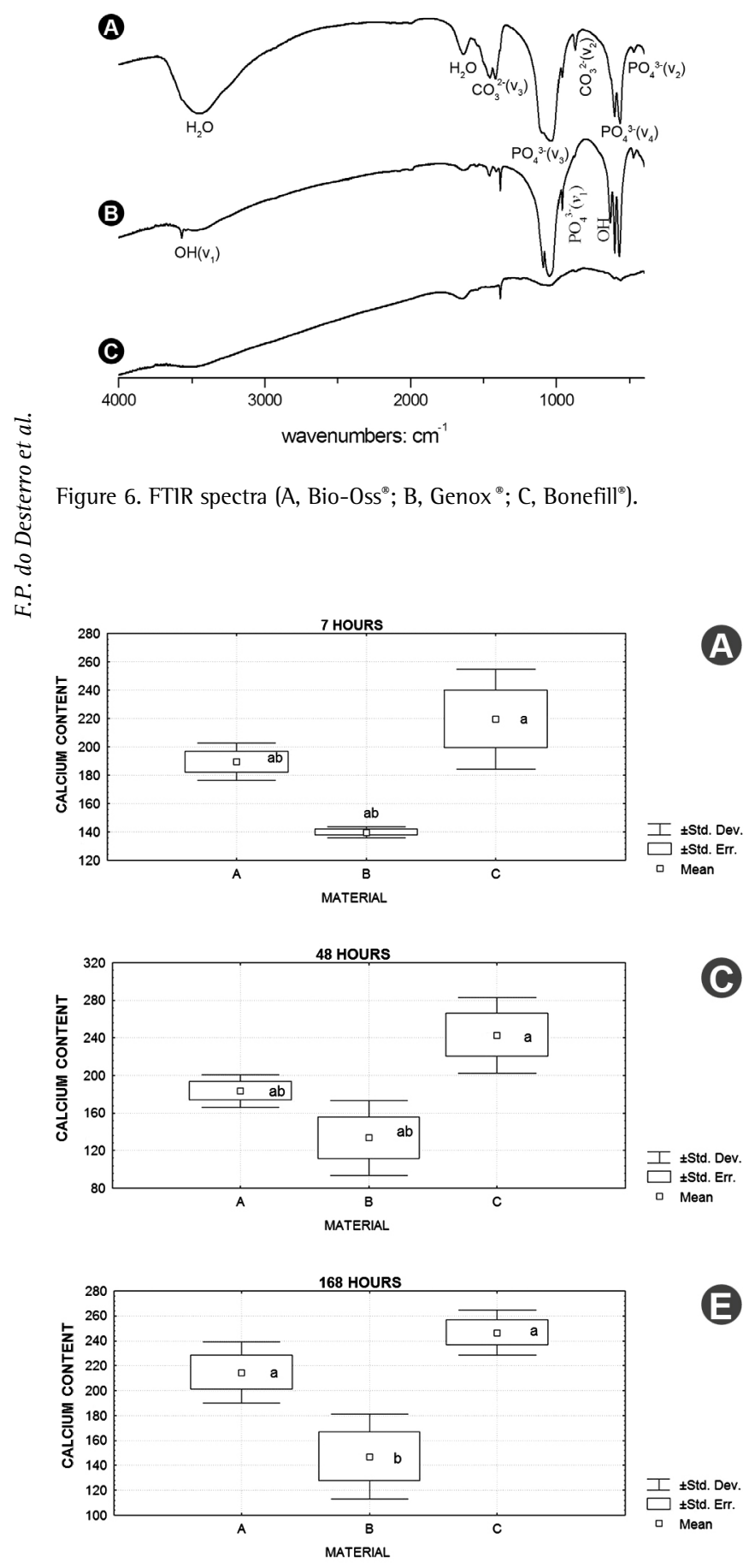

the only bovine bone inorganic biomaterial evaluated in this study, which preserved the fiber-like structure of the bone collagen to maintain the original bone morphology. This finding demonstrates that the mineral crystallites that formed within the collagen fibrils may achieve sufficient inter-crystallite bonding to retain the fibrillar structure even after dissolution of the protein template. This suggests that the manufacturing process did not alter some physicochemical properties, like crystal size. Manufacturing processes using higher temperatures can

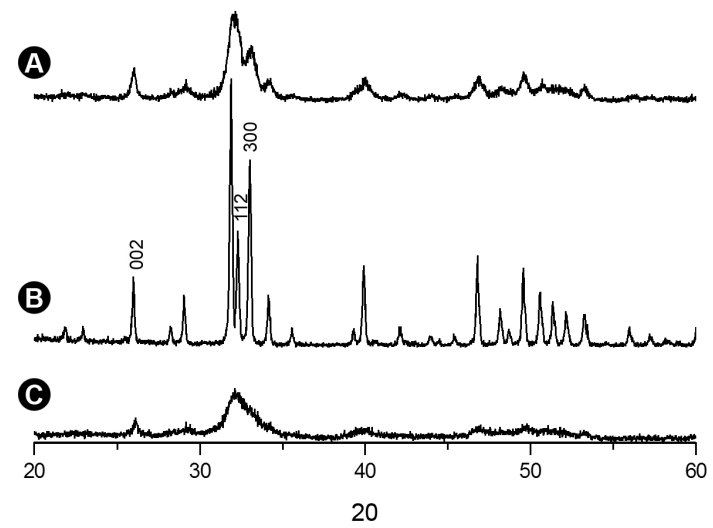

Figure 7. X-ray diffractograms (A, Bio-Oss ${ }^{\oplus}$; B, Genox ${ }^{\circledR}$; C, Bonefill ${ }^{\circledR}$.
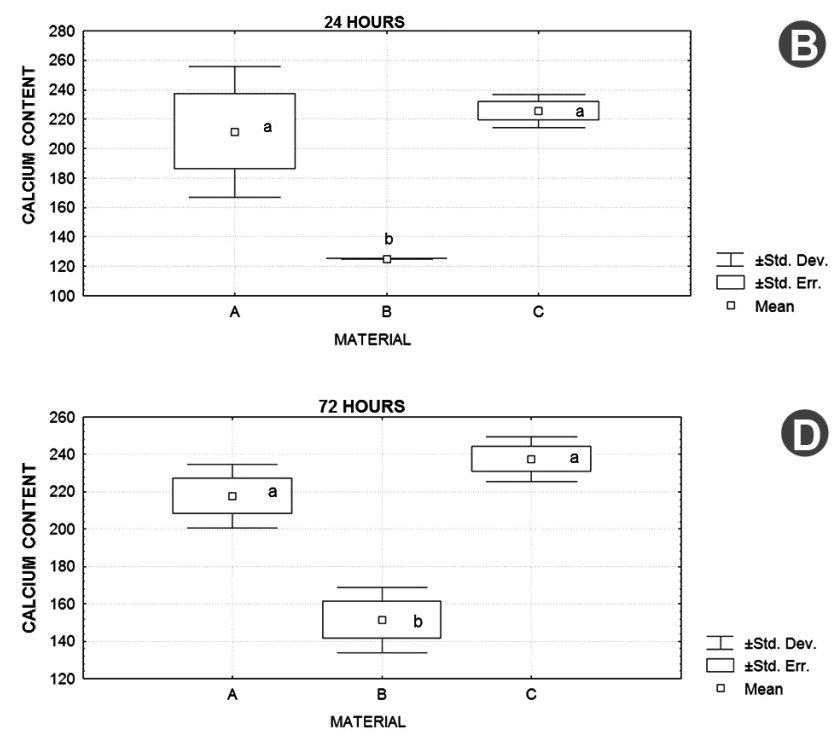

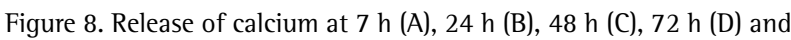
168 h (E). XX Axis: Material (A, Bio-Oss ; B, Genox ; C, Bonefill'). YY Axis: Calcium content $\left(\mathrm{mgL}^{-1}\right)$. Intragroup comparisons $(\mathrm{a} \times \mathrm{b})$ - different letters represent statistically significant differences $(\mathrm{p}<0.05)$. 
alter crystal size, producing bigger grains with higher crystallinity (17). These structural characteristics of the bone mineral phase demonstrated by Bio-Oss ${ }^{\circledast}$ could improve its osteoconductivity. GenoxInorgânico ${ }^{\oplus}$ and Bonefill ${ }^{\oplus}$ did not show the same organized structure. FEG-SEM facilitates visualization of small particles at a resolution that was only previously available by transmission electron microscopy (TEM), while maintaining the field depth that is the main characteristic of SEM. It also produces a greater level of brightness and smaller spot size, supplied by the field emission source (18). Due to these characteristics it was possible to study bovine inorganic bone grafts with highresolution and without decalcification, a common step used in TEM sample preparations, enabling the visualization of the original graft morphology.

This study showed that Bio-Oss ${ }^{\oplus}$ presented a 15-nm crystallite size. The manufacturing of this biomaterial probably maintained the original mineral scaffold consisting of nanopores, in which the cytoplasmic processes of osteocytes were located, resulting in a higher surface area $\left(86 \mathrm{~m}^{2} / \mathrm{g}\right)$, similar to the observations of another study (17). GenoxInorgânico ${ }^{\varpi}$, which has the same bone origin, had a larger HA crystallite size of $39 \mathrm{~nm}$ and a lower surface area $\left(<10 \mathrm{~m}^{2} / \mathrm{g}\right)$. The high temperatures, often used to remove the organic content of bone (9), resulted in the HA crystallite growth (19). These changes could have an impact on the in vivo biomaterial behavior $(6,9)$. The particle size of grafts and the spaces between the particles are important determinants of osteogenesis and bone regeneration (20). Although its label states that only the mineral portion remains after manufacturing, Bonefill ${ }^{\oplus}$ presented a release of substrate in the BET reactor when heated to $200^{\circ} \mathrm{C}$, suggesting presence of residual organic material. Thus, it was not possible to calculate its specific area.

In biological apatites, some phosphate ions $\left(\mathrm{PO}_{4}^{3-}\right)$ are replaced by carbonate ions $\left(\mathrm{CO}_{3}{ }^{2-}\right)$, as detected by FIIR (Fig. 6). The higher $\mathrm{CO}_{3}{ }^{2-}$ absorption band intensities indicate a high rate of incorporation of carbonate in the apatite. The resolution of the $\mathrm{PO}_{4}{ }^{3-}\left(\mathrm{v}_{3}\right)$ absorption band decreased with increasing levels of $\mathrm{CO}_{3}{ }^{2-}$ (Fig. 6A), featuring a type-B carbonated apatite. GenoxInorgânico ${ }^{\oplus}$ showed $\mathrm{OH}$ bands, a higher definition of the phosphate band, and a reduced carbonate absorption band, all characteristic of crystalline HA (Fig. 6B). High crystalline biomaterials tend to have a static behavior without remodeling (21). Thus, GenoxInorgânico ${ }^{\oplus}$ may be considered more crystalline than Bio-Oss ${ }^{\oplus}$ and Bonefill ${ }^{\oplus}$. The broader bands, observed in the FIIR spectrum of Bonefill ${ }^{\oplus}$, indicated low crystallinity (Fig. 6C). Moreover, the absorption bands of $\mathrm{PO}_{4}{ }^{3-}$ are less defined. The 1,382 band indicates the presence of $\mathrm{NO}_{3}{ }^{-}$in Bonefill ${ }^{\oplus}$. Nitrogen is a marker for the possible presence of protein within the surface layers of biomaterials (22); therefore more studies are required to investigate the presence of organic constituents in inorganic biomaterials.

Previous studies have shown that a larger diffraction peak indicates a smaller crystallite size (23). This feature was also observed in the XRD analysis of Bio-Oss ${ }^{\oplus}$ (Fig. 7A). Its higher carbonate content also resulted in wider XRD peaks, lower crystallinity and smaller crystallite size $(15 \mathrm{~nm})$. GenoxInorgânico ${ }^{\circledast}$ showed larger crystallite size $(39 \mathrm{~nm})$ and higher crystallinity based on the sharper and narrower XRD peaks (Fig. 7B). The broadening of diffraction peaks observed in the XRD of Bonefill ${ }^{\circledast}$ suggested the presence of organic material (Fig. 7C).

For bone regeneration, a biomaterial must possess essential qualitiessuch as biocompatibility, osteoconductivity, good integration and adequate resorption rate (24). Thus, a bone substitute biomaterial should be resorbable to become replaced by the native bone. In bovine-derived apatite, the dissolution was shown to be the greatest from non-sintered bone without organic matrix, followed by non-sintered bone with organic matrix, and then sintered bone. This dissolution behavior can be explained by the crystal size, which is much greater in sintered $\left(1000^{\circ} \mathrm{C}\right)$ bone than in non-sintered bone (25). This study used the dissolution test, carried out in acidic conditions (pH 5), to simulate the acid environment during osteoclastic resorption. GenoxInorgânico ${ }^{\circledast}$ was more crystalline and showed the lowest rate of calcium release in the dissolution assay. The higher rate of calcium release in Bio-Oss ${ }^{\oplus}$ and Bonefill ${ }^{\oplus}$ is attributable to their physicochemical characteristics. For Bio-Oss ${ }^{\oplus}$, its larger surface area $\left(86 \mathrm{~m}^{2} / \mathrm{g}\right)$ and lower crystallinity may facilitate a greater calcium release rate in the dissolution test using an acid environment. The associated manufacturing process largely influences these physicochemical characteristics. Bio-Oss is manufactured by heating to approximately $300^{\circ} \mathrm{C}$, followed by a chemical treatment using a $\mathrm{NaOH}$ solution $(8,22)$. Bonefill ${ }^{\oplus}$ receives only sequential bath treatments to solubilize the organic structures. Although Bio-Oss ${ }^{\circledast}$ presented a stoichiometric $\mathrm{Ca} / \mathrm{P}$ ratio, this biomaterial showed low crystallinity (as measured by XRD) and a larger amount of carbonate (as showed by FIIR), both of which are characteristics that contribute to a higher dissolution rate. The inorganic portion of the bovine bone has maintained its original architecture and chemical composition, resulting in the large surface area, as observed in Bio-Oss ${ }^{\oplus}$, resulting in its degradation when exposed to the potassium acetate solution for 7 days. Understanding the dissolution rate of various biomaterials for bone grafting is essential because this may also influence its biodegradation or bioresorption (19). Various in vivo applications may require different rates of biodegradation. A bone graft biomaterial should 
be resorbed and replaced by bone tissue.

This study has identified correlations among physicochemical characteristics of Bio-Oss ${ }^{\circledast}$, i.e. increased surface area, low crystallinity and high carbonate content, with a high rate of dissolution in acidic conditions. GenoxInorgânico ${ }^{\circledR}$, a biomaterial with a high degree of crystallinity showed a low dissolution rate. BET analysis and FTIR spectrum of Bonefill ${ }^{\circledR}$ suggests that an evaluation of organic material may be necessary. The present study evaluated biomaterials of bovine origin, and showed significant differences in their physicochemical characteristics. These differences could be related to differences in the manufacturing process and may influence the biological and clinical response.

\section{Resumo}

0 objetivo deste estudo foi avaliar as caracteristicas físico-quimicas de 3 biomateriais bovinos inorgânicos mineralizados e correlacioná-los com a taxa de dissolução. Bio-Oss ${ }^{\circledR}$, Genox Inorgânico ${ }^{\circledR}$ e Bonefill ${ }^{\circledR}$ foram caracterizados por microscopia eletrônica de varredura com fonte de emissão por efeito de campo (MEV-FEG), espectroscopia de infravermelho com transformada de Fourier (FTIR), difração de raios-X (DRX), área superficial especifica (BET), razão molar cálcio/fósforo e análise da dissolução. Bio-Oss ${ }^{\circledR}$ mostrou uma estrutura micro e nanoporosa . consistindo de cristalitos de hidroxiapatita (HA) de $15 \mathrm{~nm}$; Genox ${ }^{\circledR}$, uma estrutura microporosa composta de cristalitos de HA de 39 nm e Bonefill ${ }^{\circledR}$, estrutura micro e nanoporosa com tamanho indeterminável de cristalito. Análises de FIIR mostraram que Bio-Oss ${ }^{\circledR}$ e Genox ${ }^{\circledR}$ eram compostos por fosfato de cálcio. As bandas de absorção de fosfato encontraramse pouco definidas no Bonefill ${ }^{\circledR}$. Por DRX, Bio-Oss ${ }^{\circledR}$ mostrou picos $\Omega^{-}$relacionados à $\mathrm{HA}$ carbonatada, enquanto $\mathrm{Genox}^{\circledR}$ somente apresentou I. picos correspondentes à $\mathrm{HA}$; as bandas alargadas no Bonefill ${ }^{\circledR}$ indicaram baixa cristalinidade. Bio-Oss ${ }^{\circledR}$ apresentou maior área de superfície e taxa de liberação de cálcio quando comparado ao Genox ${ }^{\circledR}$. Embora todos os biomateriais fossem de origem bovina, os diferentes processos de manufatura resultam em materiais com diferentes propriedades físicoquímicas e podem influenciar a resposta biológica e clínica.

\section{Acknowledgements}

The authors acknowledge CAPES, CNPq and FAPERJ Brazilian agencies for the support to this study.

\section{References}

1. Juodzbalys $\mathrm{G}$, Wang HL. Socket morphology-based treatment for implant esthetics: a pilot study. Int J Oral Maxillofac Implants 2010;25:970-978.

2. Rickert D, Slater JJ, Meijer HJ, Vissink A, Raghoebar GM. Maxillary sinus lift with solely autogenous bone compared to a combination of autogenous bone and growth factors or (solely) bone substitutes. A systematic review. Int J Oral Maxillofac Surg 2012;41:160-167.

3. Graham SM, Leonidou A, Aslam-Pervez N, Hamza A, Panteliadis P, Heliotis $M$, et al.. Biological therapy of bone defects: the immunology of bone allo-transplantation. Expert Opin Biol Th 2010;10:885-901.

4. Juodzbalys G, Wang HL. Soft and hard tissue assessment of immediate implant placement: a case series. Clin Oral Implants Res 2007;18:237243.

5. Mardas N, Chadha V, Donos N. Alveolar ridge preservation with guided bone regeneration and a synthetic bone substitute or a bovine-derived xenograft: a randomized, controlled clinical trial. Clin Oral Implants Res 2010;21:688-698.
6. Rossi AL, Barreto IC, Maciel WQ, Rosa $\mathrm{FP}$, Rocha-Leão $\mathrm{MH}$, Werckmann $J$, et al.. Ultrastructure of regenerated bone mineral surrounding hydroxyapatite-alginate composite and sintered hydroxyapatite. Bone 2012;50:301-310.

7. Kim SH, Kim DY, Kim KH, Ku Y, Rhyu IC, Lee YM. The efficacy of a doublelayer collagen membrane technique for overlaying block graft in a rabbit calvarium model. Clin Oral Implants Res 2009;20:1124-1132.

8. Tadic D, Epple M. A thorough physicochemical characterization of 14 calcium phosphate-based bone substitution materials in comparison to natural bone. Biomaterials 2004;25:987-994.

9. Dorozhkin SV. Bioceramics of calcium orthophosphates. Biomaterials 2010;31:1465-1485.

10. Figueiredo $M$, Fernando $A$, Martins $G$, Freitas J, Judas F, Figueiredo $\mathrm{H}$. Effect of the calcination temperature on the composition and microstructure of hydroxyapatite derived from human and animal bone. Ceram Int 2010;36:2383-2393.

11. Lopez-Heredia MA, Bongio M, Bohner M, Cuijpers V, Winnubst LAJA, van Dijk N, et al.. Processing and in vivo evaluation of multiphasic calcium phosphate cements with dual tricalcium phosphate phases. Acta Biomater 2012;8:3500-3508.

12. Lindgren $C$, Hallman M, Sennerby L, Sammons R. Back-scattered electron imaging and elemental analysis of retrieved bone tissue following sinus augmentation with deproteinized bovine bone or biphasic calcium phosphate. Clin Oral Impl Res 2010;21:924-930.

13. Kim DK, Lee S-J, Cho TH, Hui P, Kwon M-S, Hwang SJ. Comparison of a synthetic bone substitute composed of carbonated apatite with an anorganic bovine xenograft in particulate forms in a canine maxillary augmentation model. Clin Oral Implants Res 2010;21:1334-1344.

14. Klug HP, Alexander LE. X-ray diffraction procedures for polycrystalline and amorphous materials. New York: John Wiley and Sons: 1974:618708.

15. ISO 3310-1. Test sieves - Technical requirements and testing. Part 1: Test sieves of metal wire cloth. International Organization for Standardization. Geneva: 2000:1-15.

16. ISO 10993-14. Biological evaluation of medical devices. Part 14: Identification and quantification of degradation products from ceramics. International Organization for Standardization. Geneva: 2001:1-12.

17. Conz MB, Granjeiro JM, Soares GA. Physicochemical characterization of six commercial hydroxyapatites for medical-dental applications as bone graft. J Appl Oral Sci 2005;13:136-140.

18. Rosen $V B$, Hobbs $L W$, Spector $M$. The ultrastructure of anorganic bovine bone and selected synthetic hydroxyapatites used as bone graft substitute materials. Biomaterials 2002;23:921-928.

19. LeGeros RZ. Properties of osteoconductive biomaterials: calcium phosphates. Clin Orthop Relat Res 2002;395:81-98.

20. Zhou X, Zhang Z, Li S, Bai Y, Xu H. Osteoconduction of different sizes of anorganic bone particles in a model of guided bone regeneration. $\mathrm{Br} \mathrm{J}$ Oral Maxillofac Surg 2011;49:37-41.

21. Conz MB, Granjeiro JM, Soares GA. Hydroxyapatite crystallinity does not affect the repair of critical size bone defects. J Appl Oral Sci $2011 ; 19: 337-342$

22. Taylor JC, Cuff SE, Leger JPL, Morra A, Anderson GI. In vitro osteoclast resorption of bone substitute biomaterials used for implant site augmentation: a pilot study. Int J Oral Maxillofac Implants 2002;17:321330.

23. Yao F, Legeros JP, Legeros RZ. Simultaneous incorporation of carbonate and fluoride in synthetic apatites: Effect on crystallographic and physico-chemical properties. Acta Biomater 2009;5:2169-2177.

24. Detsch $R_{1}$ Hagmeyer $D$, Neumann $M$, Schaefer $S$, Vortkamp A, Wuelling $M$, et al.. The resorption of nanocrystalline calcium phosphates by osteoclast-like cells. Acta Biomater 2010;6:3223-3233.

25. LeGeros RZ, Sakae T, Bautista C, Retino M, LeGeros JP. Magnesium and carbonate in enamel and synthetic apatites. Adv Dent Res 1996;10:225-231. 